\title{
The Sea Ice Topography of M'Clure Strait in Winter and Summer of 1960 from Submarine Profiles
}

\author{
ALFRED S. MCLAREN ${ }^{1}$, PETER WADHAMS ${ }^{2}$, and RUTH WEINTRAUB ${ }^{2}$
}

\begin{abstract}
Submarine profiles of the ice underside in M'Clure Strait were obtained by USS Sargo in February 1960 and by USS Seadragon in August 1960. They gave the first quantitative measurements of the ice draft distribution in the strait and in the nearby Beaufort Sea shelf zone, as well as providing a seasonal comparison of ice conditions within a single year. Analysis of the profiles reveals a region of very high mean ice draft (7.8 $\mathrm{m}$ ) and heavy ridging off the southwest tip of Prince Patrick Island in winter. Within M'Clure Strait itself the mean ice draft lay in the 4-5 $\mathrm{m}$ range and the draft distribution showed that the ice was mainly first-year, as opposed to the mixture of first- and multi-year ice that exists out in the Beaufort Sea. This suggests a local origin for the ice in the strait. Pressure ridges were much more frequent in summer than in winter, as were polynyas. Both the pressure ridge draft distribution (in summer) and the ice draft distribution at great depths (in summer and winter) fitted a negative exponential distribution, in common with other ice profiles which have been analysed.
\end{abstract}

Key words: sea ice, pressure ridges, sonar, M'Clure Strait, Viscount Melville Sound

RÉSUMÉ. Des profils sous-marins de la surface inférieure de la glace dans le détroit M'Clure furent obtenus par l'U.S.S. Sargo en février, 1960 et par I'U.S.S. Seadragon en août, 1960. Ceux-ci ont présentés les premières mesures quantitatives sur la distribution du tirant de la glace dans le détroit et dans la zone du plateau de la mer de Beaufort voisine, et ont aussi fourni une comparaison saisonnière des conditions glaciales pendant une année. L'analyse des profiles a révélé une région au large de l'extrémité sud-ouest de l'île Prince Patrick òu, durant l'hiver, le tirant moyen de la glace était très important $(7.8 \mathrm{~m})$ et où d'épaisses crêtes étaient formées. Dans la détroit même, le tirant moyen de la glace variait entre 4 et $5 \mathrm{~m}$ et la distribution indiquait que la glace était surtout de première année, par opposition au mélange de glace plus ágée à celle de première année que l'on trouve dans la mer de Beaufort. Cette composition suggère une origine locale pour la glace du détroit. Les cretes de pression étaient beaucoup plus fréquentes et été qu'en automne, et tel était aussi le cas pour les polynies. La distribution du tirant des crêtes de pression (durant l'été et l'hiver) suivaient une distribution exponentielle négative telle que celle d'autres profils de glace déjà analysés.

Mots clés: glace de la mer, crêtes de pression, sonar, le détroit M'Clure, le détroit Viscount Melville

Traduit pour le journal par Maurice Guibord.

\section{INTRODUCTION}

Two profiles of the underside of the sea ice in M'Clure Strait were collected by U.S. Navy submarines during the winter and summer of 1960 . They provide the first quantitative measurements of the ice draft distribution in this region, and also reveal the seasonal variation in ice topography within a single year.

The first cruise was by U.S.S. Sargo (SSN 583) from 14 to 16 February 1960. Sargo was equipped with a high-frequency narrow-beam (approximately $2^{\circ}$ ) upward-looking sonar and collected a $729-\mathrm{km}$ profile, following the track shown in Figure 1. This covered M'Clure Strait itself and the shelf area of the Beaufort Sea to the west out to a water depth of $3500 \mathrm{~m}$. The area near the mouth of M'Clure Strait has been identified by airborne and other surveys as a zone of very heavy pressure ridging. However, no ice draft profiles had been obtained from this area prior to the Sargo cruise.

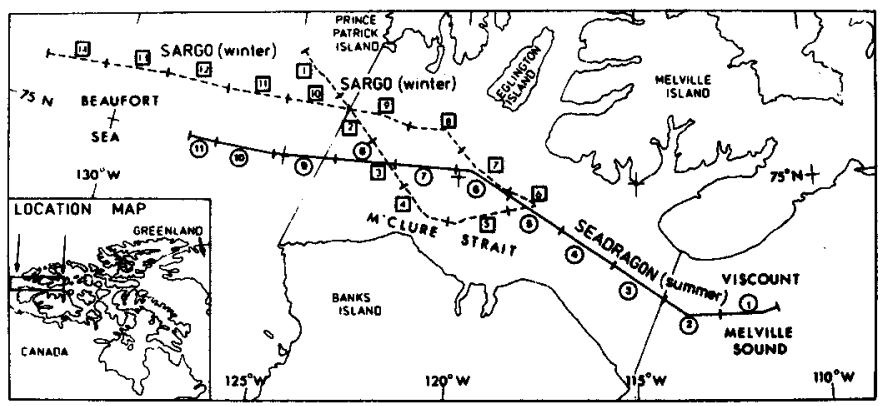

FIG. I. Cruise tracks of Seadragon and Sargo, with positions of $50-\mathrm{km} \mathrm{sec}-$ tions.
The second cruise was by U.S.S. Seadragon (SSN 584) from 20 to 21 August 1960 with a similar type of sonar (Fig. 1). Seadragon entered the ice at about $110^{\circ} \mathrm{W}$ in Viscount Melville Sound. Although the pack initially consisted of block and brash fragments it rapidly developed into an almost continuous cover containing many pressure ridges. Seadragon transited M'Clure Strait and crossed the Beaufort Sea shelf outside the strait entrance, thereby encountering the same sequence of ice regimes as Sargo. A total of $541 \mathrm{~km}$ of under-ice data was collected and analysed. An excellent general account of this cruise has been given by the submarine's Commanding Officer (Steele, 1962).

In addition to comparing these profiles with one another, we can compare them with three other data sets from the Arctic Ocean which have been analysed in the same way: an April 1976 cruise of U.S.S. Gurnard to the southern Beaufort Sea (Wadhams and Horne, 1980); an October 1976 cruise of HMS Sovereign to the western Eurasian Basin (Wadhams, 1981); and an April-May 1979 cruise of HMS Sovereign to Fram Strait and the nearby region to the north (Wadhams, 1983a):

\section{METHODS OF DATA ANALYSIS}

The measurement system aboard Sargo and Seadragon consisted of an under-ice profiling sonar which fed its output into a signal processor where the range to the underside of the ice was generated on the basis of assumed arctic sound velocities and a standard intensity level for the reflected pulse. The result was then subtracted from the transducer depth as measured by a pressure sensor, and the final signal generated a continuous

'Capt., U.S. Navy (ret'd); Department of Geography, Campus Box 260, University of Colorado, Boulder, Colorado 80309, U.S.A.

${ }^{2}$ Scott Polar Research Institute, University of Cambridge, Cambridge, CB2 1ER, England 
trace of ice draft on recording paper. The absolute accuracy was $\pm 0.15 \mathrm{~m}$, but the relative accuracy was greater since open polynyas provided zero references.

The profiles were collected for the Arctic Submarine Laboratory, San Diego, California. Through the courtesy of its Director, Dr. W.K. Lyon, they were recently declassified and sent to Scott Polar Research Institute (SPRI) where they were digitised by one of us (ASM). The digitised data were then analysed on the Cambridge University IBM 3081 computer using the same programs that had been used for the data from the Gurnard and Sovereign cruises. The input data were formed into "sections", each containing sufficient contiguous intervals of profile to make up $50 \mathrm{~km}$ of track. Statistics were then computed for each section. Figure 1 shows the positions of the 14 Sargo sections and 11 Seadragon sections; Seadragon section 11 was a short one, $23 \mathrm{~km}$ in length.
RESULTS

\section{Mean Draft}

The mean ice draft $\bar{h}$ was computed for each section and is plotted as a function of longitude in Figure 2 (listings are in Table 1). Each $50-\mathrm{km}$ average was plotted as a spot value located at the centre of the section which generated it. The area of the experiment has been divided into three zones labelled "Beaufort Sea Shelf", "M'Clure Strait" and "Viscount Melville Sound" in Figure 2, which have been marked off on Figure 1. The accuracy of each mean draft value can be estimated by examining profiles from other regions of the Arctic where ice conditions vary extremely slowly. Wadhams (1983b) found that an area of the Beaufort Sea analysed by Wadhams and Horne (1980) had homogeneous ice conditions over a region which included $2350-\mathrm{km}$ profile sections; the mean

TABLE 1. Percentages of ice cover in different ranges of draft

\begin{tabular}{|c|c|c|c|c|c|c|}
\hline $\begin{array}{l}\text { Section } \\
\text { number }\end{array}$ & $\begin{array}{c}0-0.5 \mathrm{~m} \\
\text { (Young ice) }\end{array}$ & $0-1 \mathrm{~m}$ & $\begin{array}{c}0.5-2 \mathrm{~m} \\
\text { (Intermediate } \\
\text { ice) } \\
\end{array}$ & $\begin{array}{c}2-5 \mathrm{~m} \\
\text { (Multi-year } \\
\text { and first- } \\
\text { year floes) }\end{array}$ & $\begin{array}{c}>5 \mathrm{~m} \\
\text { Deformed } \\
\text { ice }\end{array}$ & $\begin{array}{c}\text { Mean draft } \\
\text { of section } \\
\mathrm{m}\end{array}$ \\
\hline \multicolumn{7}{|l|}{ Sargo (winter) } \\
\hline 1 & 0.2 & 0.5 & 6 & 30 & 63 & 7.30 \\
\hline 2 & 1.6 & 5.0 & 16 & 47 & 35 & 4.72 \\
\hline 3 & 3.5 & 7.6 & 26 & 38 & 33 & 4.33 \\
\hline 4 & 0.1 & 1.4 & 27 & 52 & 20 & 3.54 \\
\hline 5 & 0.0 & 1.3 & 32 & 35 & 33 & 4.49 \\
\hline 6 & 0.7 & 1.4 & 38 & 25 & 36 & 4.83 \\
\hline 7 & 1.1 & 2.2 & 37 & 29 & 33 & 4.44 \\
\hline 8 & 0.2 & 5.8 & 25 & 39 & 36 & 4.77 \\
\hline 9 & 0.2 & 1.2 & 7 & 21 & 73 & 7.77 \\
\hline 10 & 0.0 & 0.5 & 5 & 43 & 52 & 6.40 \\
\hline 11 & 0.5 & 1.3 & 4 & 50 & 45 & 5.58 \\
\hline 12 & 1.1 & 3.8 & 13 & 47 & 39 & 5.12 \\
\hline 13 & 0.6 & 14.1 & 31 & 45 & 23 & 3.79 \\
\hline 14 & 0.0 & 1.7 & 11 & 58 & 31 & 4.55 \\
\hline \multicolumn{7}{|c|}{ Seadragon (summer) } \\
\hline 1 & 4.2 & 18.6 & 74 & 22 & 0 & 1.57 \\
\hline 2 & 4.8 & 28.2 & 64 & 28 & 3 & 1.81 \\
\hline 3 & 5.0 & 16.9 & 59 & 31 & 5 & 2.16 \\
\hline 4 & 0.9 & 5.2 & 27 & 54 & 18 & 3.52 \\
\hline 5 & 0.1 & 5.1 & 19 & 50 & 31 & 4.52 \\
\hline 6 & 10.1 & 16.8 & 15 & 46 & 28 & 4.14 \\
\hline 7 & 2.4 & 20.4 & 23 & 50 & 25 & 3.91 \\
\hline 8 & 7.5 & 37.6 & 35 & 41 & 16 & 3.04 \\
\hline 9 & 13.4 & 34.6 & 34 & 43 & 10 & 2.68 \\
\hline 10 & 12.8 & 26.7 & 31 & 45 & 11 & 2.60 \\
\hline 11 & 1.7 & 24.9 & 59 & 35 & 4 & 1.94 \\
\hline \multicolumn{7}{|c|}{ Gurnard (Beaufort Sea north of Alaska, winter) } \\
\hline $\begin{array}{l}\mathrm{G} \mu \\
\text { (average) }\end{array}$ & 0.9 & 3.4 & 10 & 71 & 19 & 3.81 \\
\hline $\begin{array}{l}\text { G1 } \\
\text { (heavy ice) }\end{array}$ & 1.2 & 4.5 & 11 & 47 & 41 & 5.09 \\
\hline \multicolumn{7}{|c|}{ Sovereign (Eurasian Basin, October) } \\
\hline $\begin{array}{l}S_{\mu} \\
\text { (average) }\end{array}$ & 2.6 & - & 11 & 58 & 28 & 4.51 \\
\hline $\begin{array}{l}\text { S10 } \\
\text { (heavy ice) }\end{array}$ & 2.5 & - & 4 & 38 & 55 & 7.49 \\
\hline
\end{tabular}




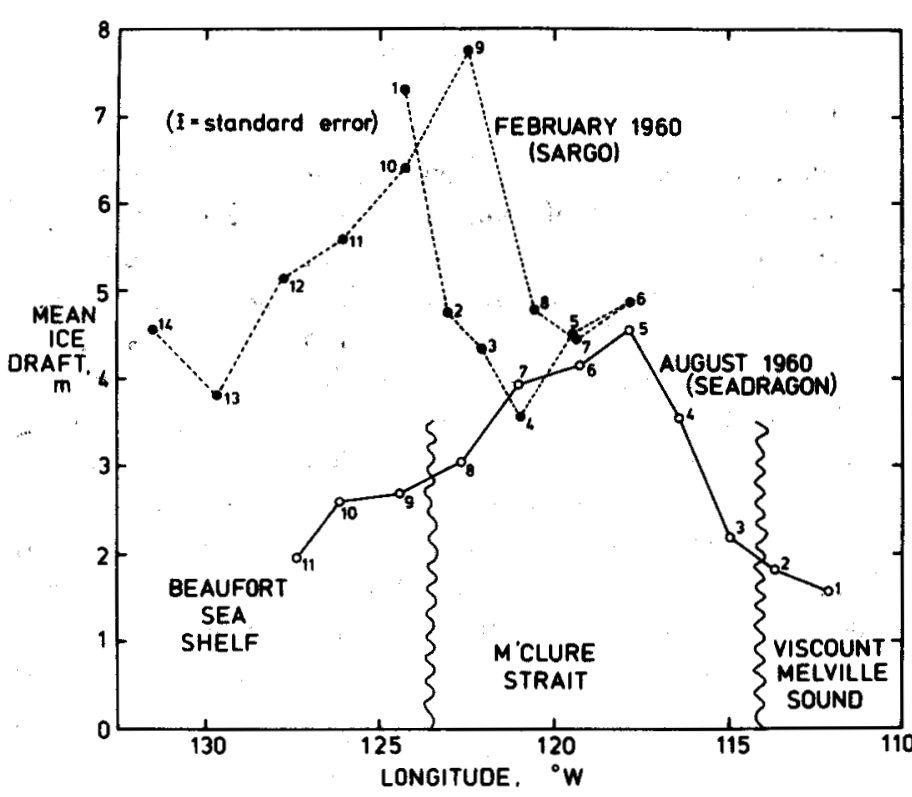

FIG. 2. Mean ice draft along Sargo and Seadragon tracks, plotted as a function of longitude.

drafts had a standard deviation of $0.06 \mathrm{~m}$. We can then take $\pm 0.06 \mathrm{~m}$ as the standard error in each of the mean draft values of Figure 2.

Mean ice draft can be converted to mean ice thickness by multiplying by the ratio 1.12 , assuming a water density of 1020 and an ice density of $910 \mathrm{~kg} \cdot \mathrm{m}^{-3}$. Ackley et al. (1976) describe more complex procedures which allow for ice density variation with depth and for a contribution from snow cover; they must be applied to the whole ice profile. Mean ice draft, however, is a useful concept to retain, since it is a direct measure of the mass of ice per unit area of sea surface.

\section{Probability Density Function of Ice Draft}

The probability density function of ice draft $P(h)$ is defined such that $P(h)$ dh is the probability that a random point on the ice underside has a draft between $h$ and $(h+d h)$. Figures 3-7 show $\mathrm{P}(\mathrm{h})$ for the $50-\mathrm{km}$ sections mapped in Figure 1. The sections are grouped slightly differently from the three divisions of Figure 1, mainly on the basis of family resemblances in the shapes of $P(h)$. Figure 3 covers Sargo sections 1 and 9-14 from the winter Beaufort Sea Shelf; section 9, although just inside the northern entrance to $M$ 'Clure Strait, is included here because of its similarity to section 1. Figure 4 shows the Sargo sections from the interior of $\mathbf{M}^{\prime}$ Clure Strait in winter. Figure 5 shows Seadragon sections 1-4 from Viscount Melville Sound and the eastern part of $M^{\prime}$ Clure Strait in summer, and Figure 6 continues the Seadragon track through central M'Clure Strait. Figure 7 shows Seadragon section 8, from the central part of the strait entrance, and sections 9-11 from the Beaufort Sea Shelf in summer.

When integrated over ranges of draft, $P(h)$ becomes an indicator of the composition of the ice cover. We have chosen the following ranges which we think are critical:

1) $0-0.5 \mathrm{~m}$ and $0-1 \mathrm{~m}$ comprise young ice. The $0-1 \mathrm{~m}$ range includes the large amount of open water found in the icefield in summer, and in winter it covers leads which are still open or which have refrozen very recently.

2) 0.5-2 m comprises intermediate ice, i.e. first-year ice of age ranging from a few days to a few months.

3) 2-5 $\mathrm{m}$ is a draft range typical of undeformed multi-year and thick first-year ice, although it must also include some contributions from ridging.

4) $>5 \mathrm{~m}$ covers ice which is undoubtedly deformed.

Table 1 shows the percentages of ice contained within these draft ranges. Table 1 also presents representative values from the Gurnard and Sovereign cruises. ' $\mathrm{G} \mu$ ' was the average of
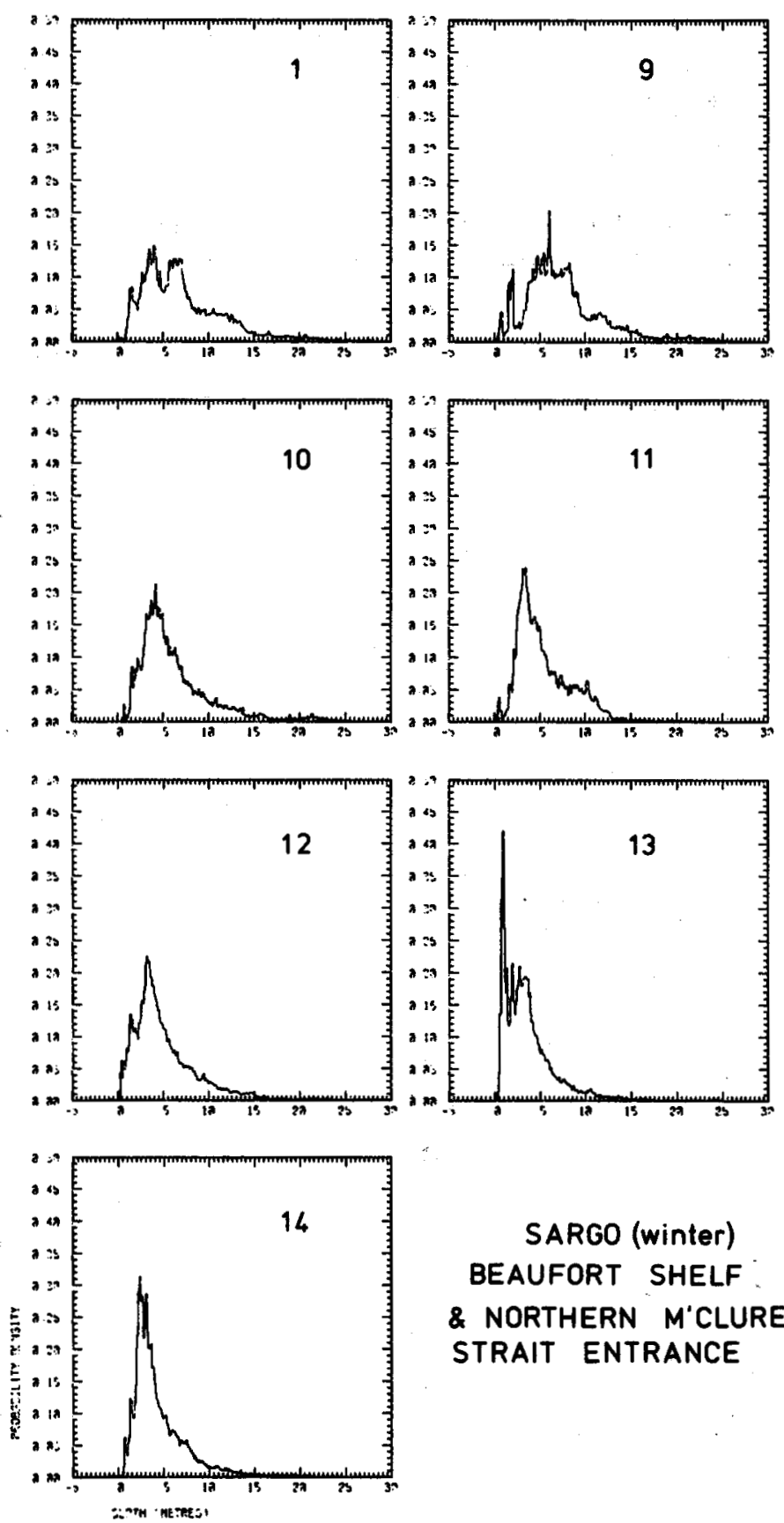

\section{SARGO (winter) \\ BEAUFORT SHELF \\ \& NORTHERN M'CLURE STRAIT ENTRANCE}

FIG. 3. Probability density functions $\mathbf{P ( h )}$ of ice draft for Sargo sections 1, 9.14. 


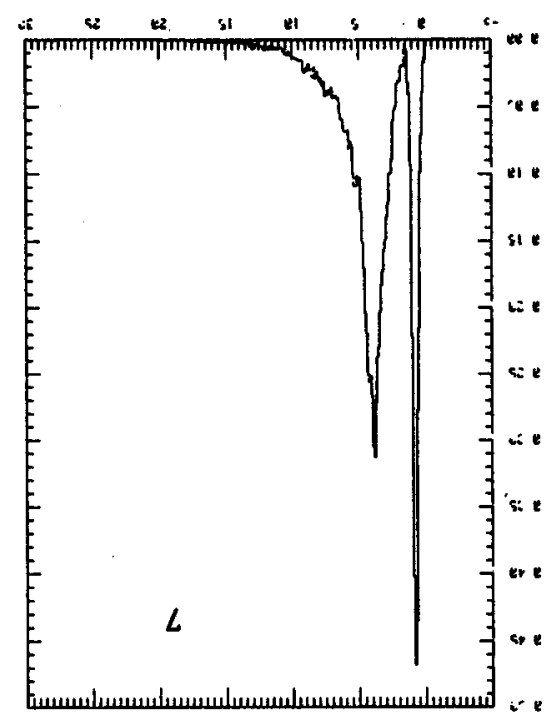

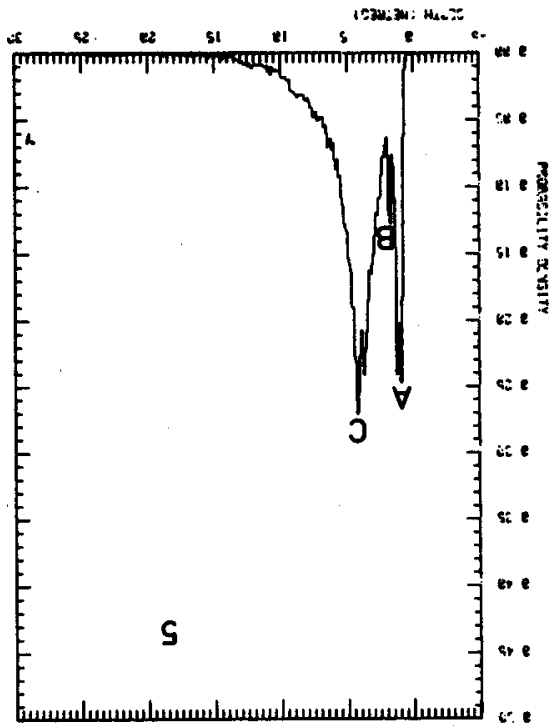

NOS $\forall$ Y0 $\forall \exists S$ (Jowwns)

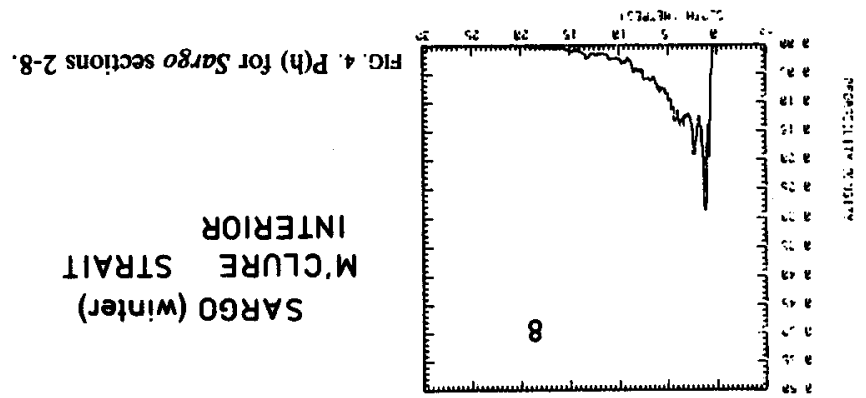

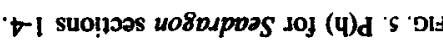
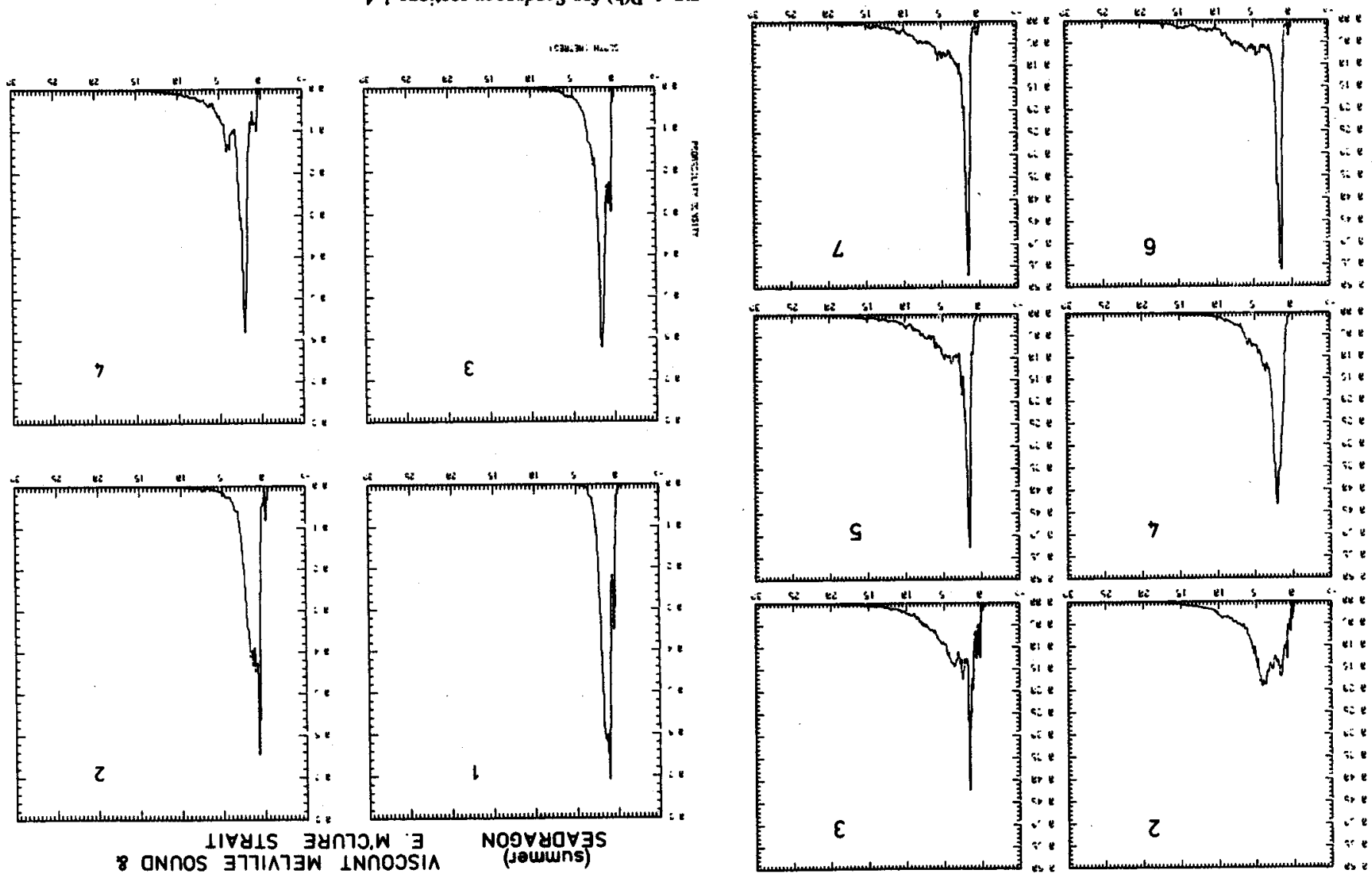

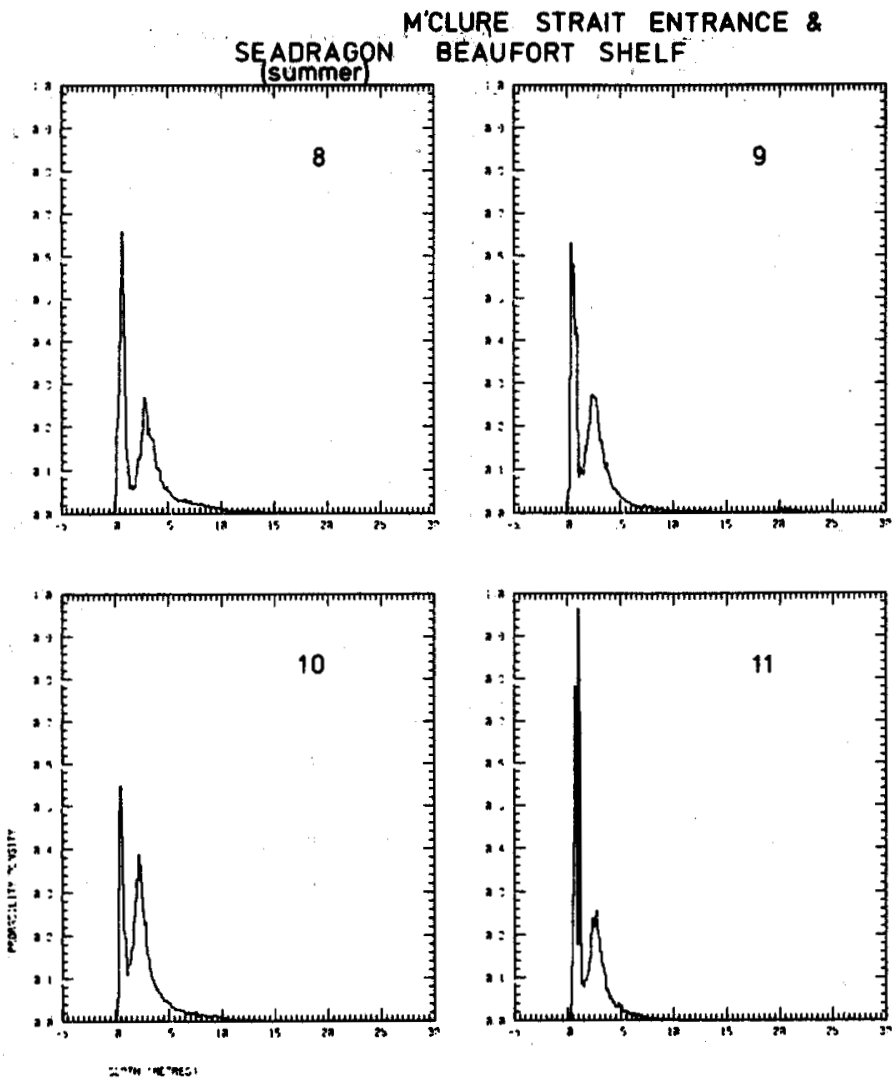

FIG. 7. P(h) for Seadragon sections 8-11.

sections in the southern Beaufort Sea, north of Alaska, in April 1976, while 'Gl' was the most heavily ridged Gurnard section, running northwards from the $100-\mathrm{m}$ isobath off Barter Island. Similarly, ' $\mathrm{S} \mu$ ' is the average of ice conditions in the western Eurasian Basin in October 1976, while 'SlO' was the most heavily ridged section from some $150 \mathrm{~km}$ north of Ellesmere Island.

Previous analyses of ice profiles have shown that the tail of the $P(h)$ function, i.e. at drafts where the only ice present must be in keels, takes a negative exponential form (Wadhams and Horne, 1980; Wadhams, 1981). The physical explanation for this is unknown. The present data were tested by combining the sections comprising each of Figures 3-7 and plotting on semilogarithmic paper at $1-\mathrm{m}$ depth increments. Figure 8 shows that all five distributions fit a negative exponential in the draft range 5-15 m, with deviations at greater depths which are in part pure statistical variability (due to the small number of points per bin) but in part represent real accumulations of ice in particular draft ranges. The slope and intercept of the exponential region of the curves are measures of the amount and distribution of ridged ice in the region concerned, and clearly indicate a greater amount of ridging in winter than in summer.

\section{Level Ice}

An informative statistic which describes the composition of the ice cover is the distribution of level ice draft, since this picks out the types of undeformed ice which make up the ice-

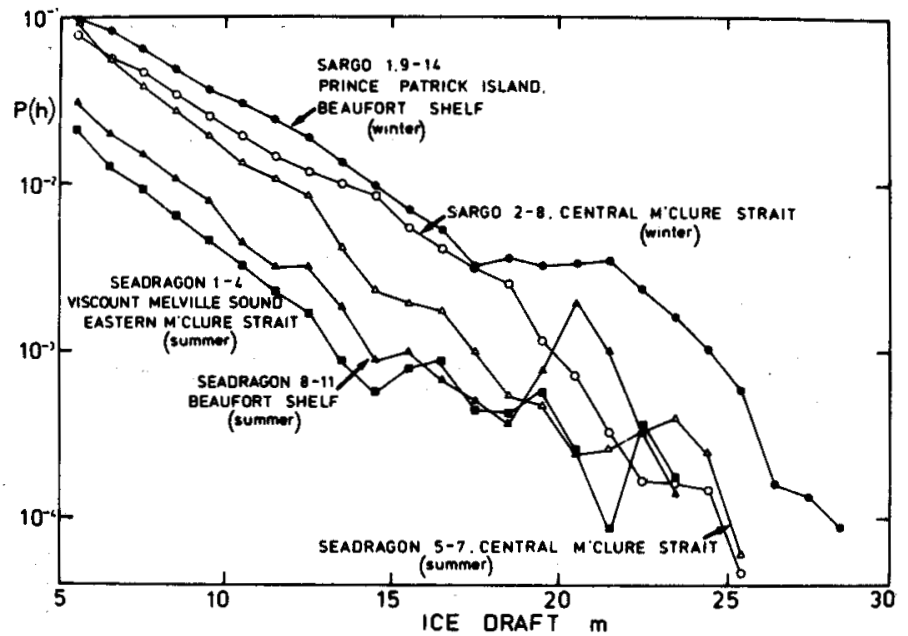

FIG. 8. $P(h)$ integrated into $1-m$ draft increments and plotted for the combined data of Figures 3-7 on semilogarithmic scale.

field. A "level ice" point is defined as a point whose draft differs from that of a point $10 \mathrm{~m}$ to either side by less than $25 \mathrm{~cm}$ (Williams et al., 1975; Wadhams, 1981). This is equivalent to saying that level ice has a local gradient of less than 1 in 40 .

For each 50-km section, Table 2 shows the percentage of the ice profile which is composed of level ice defined in this way. The distributions of level ice were computed in 10-cm draft increments, and Table 2 also shows the bins which contain the greatest concentrations of level ice, both in the young ice

TABLE 2. Distribution of level ice

\begin{tabular}{|c|c|c|c|c|c|}
\hline \multirow{2}{*}{\multicolumn{2}{|c|}{$\begin{array}{lc}\text { Section } & \begin{array}{c}\text { Percentage } \\
\text { level ice }\end{array} \\
\text { Sargo (winter) }\end{array}$}} & \multicolumn{2}{|c|}{$\begin{array}{c}\text { Two depths }<1 \mathrm{~m} \\
\text { with highest } \\
\text { frequencies of } \\
\text { level ice }\end{array}$} & \multicolumn{2}{|c|}{$\begin{array}{c}\text { Two depths }>1 \mathrm{~m} \\
\text { with highest } \\
\text { frequencies of } \\
\text { level ice }\end{array}$} \\
\hline & & & & & \\
\hline 1 & 56.1 & 0.9 & 0.0 & 3.5 & 4.0 \\
\hline 2 & 51.1 & 0.9 & 0.4 & 1.7 & 1.6 \\
\hline 3 & 49.2 & 0.2 & 0.7 & 1.6 & 1.5 \\
\hline 4 & 53.5 & 0.9 & 0.7 & 2.1 & 2.0 \\
\hline 5 & 66.5 & 0.9 & 0.8 & 1.5 & 1.6 \\
\hline 6 & 61.0 & $\mathbf{0 . 3}$ & 0.9 & 1.4 & 1.6 \\
\hline 7 & 65.6 & 0.9 & 0.2 & 1.5 & 1.4 \\
\hline 8 & 54.0 & 0.8 & $0: 9$ & 1.2 & 1.1 \\
\hline 9 & 51.2 & 0.8 & 0.7 & 6.0 & 2.0 \\
\hline 10 & 47.5 & 0.7 & 0.9 & 4.2 & 3.7 \\
\hline 11 & 52.1 & 0.5 & 0.4 & 3.1 & 3.4 \\
\hline 12 & 45.3 & 0.4 & 0.6 & 3.2 & 3.3 \\
\hline 13 & 65.4 & 0.9 & 0.8 & 1.0 & 1.3 \\
\hline 14 & 55.0 & 0.7 & 0.8 & 2.4 & 2.3 \\
\hline \multicolumn{6}{|c|}{ Seadragon (summer) } \\
\hline 1 & 48.6 & 0.5 & 0.4 & 1.1 & 1.0 \\
\hline 2 & 56.4 & 0.6 & 0.7 & 1.0 & 1.1 \\
\hline 3 & 64.2 & 0.4 & 0.7 & 1.6 & 1.7 \\
\hline 4 & 62.6 & 0.5 & 0.8 & 2.0 & 1.9 \\
\hline 5 & 39.1 & 0.9 & 0.8 & 1.2 & 1.0 \\
\hline 6 & 53.1 & 0.4 & 0.3 & 3.5 & 3.6 \\
\hline 7 & 57.2 & 0.8 & 0.7 & 1.0 & 3.8 \\
\hline 8 & 60.0 & 0.7 & 0.8 & 1.0 & 2.8 \\
\hline 9 & 64.7 & 0.5 & 0.6 & 2.2 & 2.3 \\
\hline 10 & 57.4 & 0.5 & 0.3 & 2.2 & 2.3 \\
\hline 11 & 69.4 & 0.9 & 0.7 & 1.0 & 1.1 \\
\hline
\end{tabular}


range (0-1 m draft) and in the older ice range ( $>1 \mathrm{~m}$ draft). This indicates the types of thermodynamically-grown ice which are most characteristic of the icefield.

\section{Pressure Ridges}

When analysing an ice profile by computer it is necessary to use an arbitrary criterion to define an independent pressure ridge keel, since ridges often overlap or cross one another and are therefore difficult to distinguish. In this analysis independent pressure ridges are defined, as in Wadhams and Horne (1980) and Wadhams $(1981,1983 a, b)$, by the Rayleigh criterion: that a keel is independent if the troughs (points of minimum draft) on either side of the crest (point of maximum draft) rise at least halfway towards the local level ice bottom before beginning to descend again. The "level bottom" is defined arbitrarily as being at $2.5 \mathrm{~m}$ draft since it is difficult to locate in heavily ridged areas. This definition is designed to separate truly independent keels (i.e. keels produced by independent deformation events) from the multiple peaks which occur due to block-scale roughness within a single keel. The problems involved in keel definition have been discussed by Hibler (1975) and Rothrock and Thorndike (1980).

Using this definition, keel draft distributions were computed for all sections. Table 3 summarises the results, showing the number of keels per $\mathrm{km}$ of track which are deeper than $5 \mathrm{~m}$ and $9 \mathrm{~m}$ respectively, with the mean keel drafts in each case. It also gives the draft of the deepest keel. Wadhams (1981) noted a strong positive correlation between keel frequency and mean keel draft, but analysis of Table 3 shows only a weak correlation at a $9 \mathrm{~m}$ cutoff ( $r=0.21$ for Sargo and 0.43 for Seadragon), while at a $5 \mathrm{~m}$ cutoff Seadragon has a strong positive correlation $(r=0.72)$ but Sargo a weak negative correlation $(r=-0.37)$. No conclusions can be drawn from this.

The overall distribution of keel drafts is plotted in Figure 9. Earlier studies have shown that narrow-beam sonar data from the southern Beaufort Sea (Wadhams and Horne, 1980) fitted a simple negative exponential distribution

$$
\text { n (h) } d h=B \exp (-b h) d h
$$

where $n(h)$ is the number of keels per $k m$ of track per $m$ of draft increment and $\mathrm{B}, \mathrm{b}$ are parameters that can be calculated from $h_{0}$ (low draft cutoff), $\hbar$ (mean draft) and $\mu$ (mean number of keels per $\mathrm{km}$ ) using

$$
\begin{gathered}
b=\left(\hbar-h_{0}\right)^{-1} \\
B=\mu b \exp \left(b h_{0}\right)
\end{gathered}
$$

Wide-beam sonar data from the Eurasian Basin, however, (Wadhams, 1981) fitted a distribution proposed by Hibler et al. (1972):

$$
n\left(h^{\prime}\right)=A \exp \left(-\lambda h^{\prime 2}\right) d h^{\prime}
$$

where $A, \lambda$ are parameters that can be determined from $h_{0}$ and $h$ and $h^{\prime}$ is the keel relief relative to undeformed ice, i.e. $h^{\prime}=$ (h -2.5 ). Wadhams (1981) found a good fit to this distribution, except at extremely high drafts.

Figure 9 shows that the summer data from Seadragon give a

\begin{tabular}{|c|c|c|c|c|c|}
\hline \multirow[t]{2}{*}{ Section } & \multicolumn{2}{|c|}{$\begin{array}{l}\text { Ridges deeper than } \\
5 \mathrm{~m}\end{array}$} & \multicolumn{2}{|c|}{$\begin{array}{c}\text { Ridges deeper than } \\
9 \mathrm{~m}\end{array}$} & \multirow[t]{2}{*}{$\begin{array}{c}\text { Maximum } \\
\text { draft } m\end{array}$} \\
\hline & $\begin{array}{c}\text { No. per } \\
\text { km }\end{array}$ & $\begin{array}{c}\text { Mean } \\
\text { draft m }\end{array}$ & $\begin{array}{c}\text { No. per } \\
\text { km }\end{array}$ & $\begin{array}{c}\text { Mean } \\
\text { draft m }\end{array}$ & \\
\hline \multicolumn{6}{|c|}{ Sargo (winter) } \\
\hline 1 & 1.45 & 11.22 & 0.84 & 14.18 & 27.75 \\
\hline 2 & 2.16 & 8.52 & 0.81 & 11.60 & 18.32 \\
\hline 3 & 2.27 & 9.11 & 0.95 & 12.30 & 23.63 \\
\hline 4 & 2.11 & 8.03 & 0.54 & 12.33 & 25.71 \\
\hline 5 & 1.31 & 9.58 & 0.66 & 12.42 & 21.23 \\
\hline 6 & 1.52 & 10.74 & 0.79 & 14.02 & 25.23 \\
\hline 7 & 1.32 & 9.79 & 0.64 & 12.72 & 21.05 \\
\hline 8 & 2.44 & 9.73 & 1.18 & 12.90 & 23.55 \\
\hline 9 & 1.77 & 11.67 & 1.18 & 13.84 & 29.03 \\
\hline 10 & 2.05 & 9.66 & 0.98 & 12.84 & 25.52 \\
\hline 11 & 2.10 & 9.02 & 0.92 & 11.90 & 22.97 \\
\hline 12 & 2.59 & 9.36 & 1.10 & 12.67 & 23.59 \\
\hline 13 & 1.40 & 8.70 & 0.48 & 12.82 & 24.51 \\
\hline 14 & 2.00 & 8.83 & 0.75 & 12.30 & 21.69 \\
\hline \multicolumn{6}{|c|}{ Seadragon (summer) } \\
\hline 1 & 0.06 & 7.70 & 0.02 & 12.73 & 12.73 \\
\hline 2 & 0.89 & 6.90 & 0.17 & 10.36 & 13.54 \\
\hline 3 & 1.77 & 7.94 & 0.43 & 11.96 & 23.64 \\
\hline 4 & 3.78 & 8.98 & 1.35 & 12.70 & 23.66 \\
\hline 5 & 7.59 & 8.62 & 2.43 & 12.52 & 27.52 \\
\hline 6 & 5.89 & 8.61 & 2.19 & 12.18 & 20.38 \\
\hline 7 & 5.44 & 8.44 & 1.88 & 11.70 & 21.44 \\
\hline 8 & 4.23 & 8.48 & 1.36 & 12.23 & 21.78 \\
\hline 9 & 2.71 & 7.69 & 0.61 & 12.23 & 23.98 \\
\hline 10 & 3.17 & 7.93 & 0.87 & 11.53 & 26.13 \\
\hline 11 & 2.05 & 6.77 & 0.17 & 10.53 & 12.54 \\
\hline
\end{tabular}
good fit to the simple distribution (1). The fit of Sargo data to (1) is also quite good at depths exceeding $9 \mathrm{~m}$, but in the $5-9 \mathrm{~m}$
TABLE 3. Pressure ridge frequencies and mean drafts

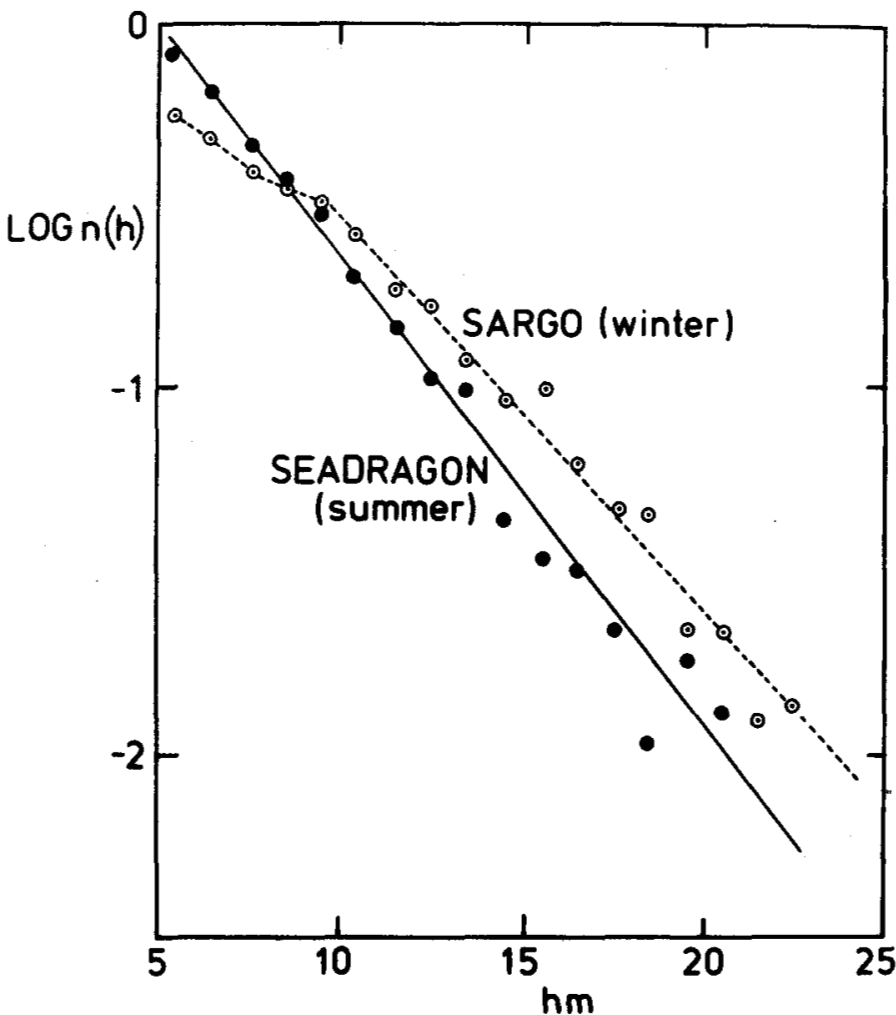

FIG. 9. $n(h)$, the number of keels per $k m$ of track per $m$ of draft increment, plotted against draft on a semilogarithmic scale for the overall Sargo and Seadragon datasets. 
depth range there is a scarcity of keels. Lowry and Wadhams (1979) showed how such a scarcity can occur, especially in regions of heavy riding, owing to the overlap of keels which prevents some shallow keels from appearing in the statistics.

We note that since keel frequencies fall off more slowly with increasing draft in the Sargo data, extrapolation to longer track lengths predicts a greater maximum keel draft in a given area of icefield in winter than in summer. This naturally implies that if the ice is in motion it will scour the seabed out to a greater water depth in winter than in summer (Wadhams, 1983c).

\section{Leads and Polynyas}

The function $P(h)$ describes the fraction of the icefield occupied by young ice of varying thicknesses, but it does not describe how that young ice is distributed spatially among refrozen leads and polynyas (a polynya is defined as an opening which is of random shape rather than being long and narrow like a lead; in a one-dimensional profile it is impossible to distinguish between a lead and a polynya). The distribution of leads and polynyas is important operationally for its application to submarine surfacing and aircraft landing sites, and scientifically since the lead distribution indicates the capacity of the ice cover to sustain deformation by convergence or shear.

For the purpose of this analysis a "polynya" was defined as a continuous stretch of ice profile at least $5 \mathrm{~m}$ in length within

TABLE 4. Polynya frequencies and mean widths

\begin{tabular}{|c|c|c|c|c|}
\hline Section & & $\begin{array}{c}\text { Number of } \\
\text { polynyas } \\
\text { within section }\end{array}$ & $\begin{array}{c}\text { Mean width } \\
\text { m }\end{array}$ & $\begin{array}{c}\text { Percentage of } \\
\text { surface occupied } \\
\text { by polynyas }\end{array}$ \\
\hline \multicolumn{5}{|c|}{ Sargo (winter) } \\
\hline 1 & & 15 & 16.93 & 0.48 \\
\hline 2 & & 47 & 53.81 & 4.83 \\
\hline 3 & & 103 & 36.78 & 7.59 \\
\hline 4 & & 69 & 10.51 & 1.32 \\
\hline 5 & & 26 & 25.42 & 1.27 \\
\hline 6 & & 32 & 22.38 & 1.36 \\
\hline 7 & & 27 & 41.33 & 2.18 \\
\hline 8 & & 83 & 37.67 & 5.68 \\
\hline 9 & & 16 & 57.75 & 1.72 \\
\hline 10 & & 9 & 25.33 & 0.47 \\
\hline 11 & & 14 & 46.07 & 1.33 \\
\hline 12 & & 50 & 40.84 & 3.73 \\
\hline 13 & & 68 & 96.48 & 13.81 \\
\hline 14 & & 17 & 54.65 & 1.70 \\
\hline \multicolumn{5}{|c|}{ Seadragon (summer) } \\
\hline 1 & & 720 & 12.98 & 18.40 \\
\hline 2 & & 651 & 22.18 & 28.04 \\
\hline 3 & & 352 & 24.53 & 16.83 \\
\hline 4 & & 54 & 48.51 & 5.11 \\
\hline 5 & & 70 & 34.84 & 4.90 \\
\hline 6 & & 87 & 105.32 & 16.75 \\
\hline 7 & & 96 & 110.14 & 19.91 \\
\hline 8 & & 132 & 124.52 & 32.36 \\
\hline 9 & & 144 & 127.91 & 34.24 \\
\hline 10 & : & 166 & 83.10 & 26.67 \\
\hline $11 \cdots$ & & 89 & 83.96 & 32.63 \\
\hline
\end{tabular}

which no draft exceeds $1 \mathrm{~m}$; this definition was also used in Wadhams and Horne (1980) and Wadhams (1981). For each section Table 4 shows the number of polynyas detected, their average width in the direction of the profile, and the percentage of the total ice profile occupied by polynyas (an unbiased, though inefficient, estimator of the fractional area of the ice cover occupied by polynyas). It is immediately clear that polynya frequencies and widths are much greater in summer than in winter, except in the centre of M'Clure Strait.

Table 5 shows, for the pooled data from each submarine voyage, the distribution of polynya widths. This is plotted graphically in Figure 10, a "trafficability diagram" which shows,

TABLE 5. Distribution of polynya widths

\begin{tabular}{rcc}
\hline \hline Width $\mathrm{m}$ & \multicolumn{2}{c}{ Number per $100 \mathbf{k m}$} \\
\hline & $\begin{array}{c}\text { Seadragon } \\
\text { (summer) }\end{array}$ & $\begin{array}{c}\text { Sargo } \\
\text { (winter) }\end{array}$ \\
\cline { 2 - 3 } $5-50$ & 398.6 & 65.6 \\
$50-100$ & 29.1 & 5.4 \\
$100-150$ & 10.3 & 2.9 \\
$150-200$ & 7.8 & 1.3 \\
$200-250$ & 4.3 & 1.1 \\
$250-300$ & 4.3 & 0.3 \\
$300-350$ & 1.5 & 0.6 \\
$350-400$ & 1.3 & 0.6 \\
$400-450$ & 3.1 & 0.1 \\
$450-500$ & 1.7 & 0.3 \\
$500-600$ & 1.5 & 0.3 \\
$600-700$ & 1.5 & 0.3 \\
$700-800$ & 0.9 & \\
$800-900$ & 0.7 & 0.1 \\
$900-1000$ & 0.6 & \\
$1000-1200$ & 0.7 & 0.3 \\
$1200-1400$ & 0.7 & - \\
$1400-1600$ & 0.7 & - \\
$1600-2350$ & 0.4 & - \\
\hline \hline
\end{tabular}

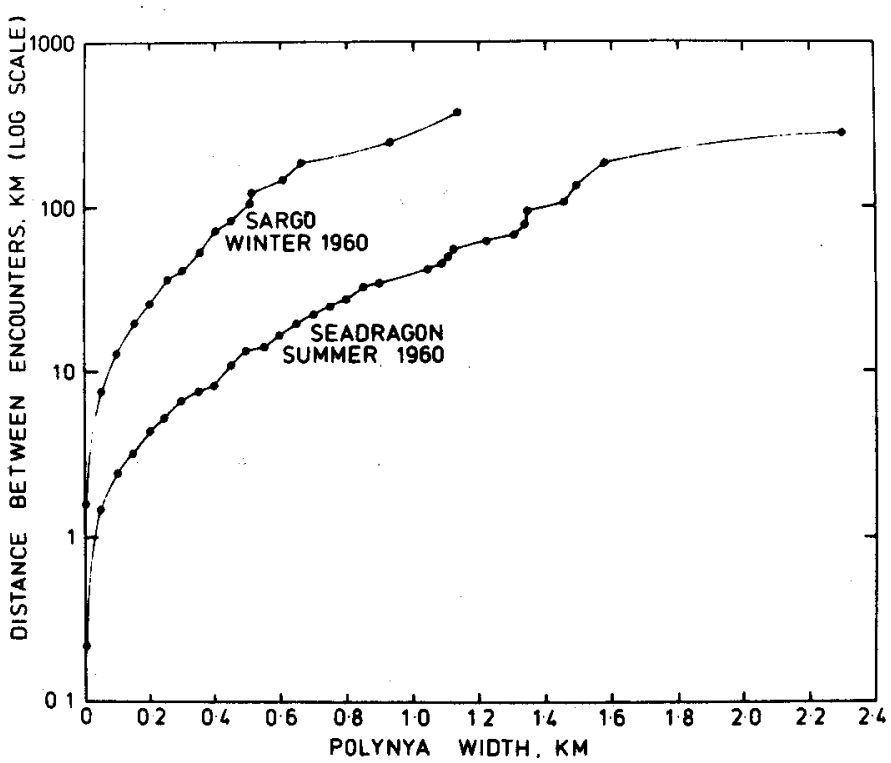

FIG. 10. Trafficability diagram for polynyas encountered in winter and summer 1960. 
for each polynya width, the distance that must be travelled on average between encounters with a polynya of that width or greater. Comparison with the trafficability diagrams for the southern Beaufort Sea (Wadhams and Horne, 1980:423) and the western Eurasian Basin (Wadhams, 1981:83) shows that the overall polynya frequency in the experimental region in winter is smaller than in the Eurasian Basin but greater than in the southern Beaufort Sea. In summer the frequency of encounter with polynyas is about a factor of 10 greater than in winter.

\section{DISCUSSION}

The unique value of these two data sets lies in the fact that a well-defined part of the Northwest Passage encompassing a variety of ice regimes has been profiled in the winter and summer of a single year. Our discussion therefore focusses on regional variations within a single season, and seasonal variations for each region covered by the profile.

\section{Regional Variations: Winter}

During winter the heaviest ice cover in the experimental area occurs off the southwest tip of Prince Patrick Island at the $M$ 'Clure Strait entrance. This region is known to be a major source area for "multi-year hummock fields" (R.D. Hudson, pers. comm. 1981), defined as extensive coherent ice masses, several kilometres in diameter and intensively ridged, which break away from the nearshore zone and drift down into the southern Beaufort Sea. The mean drafts in Sargo sections 1 and 9-12 (Table 1, Fig. 2) exceed those in the most intensively ridged part of the Alaskan shear zone (G1), and the section 9 draft of $7.77 \mathrm{~m}$ even exceeds $\mathrm{S} 10$, which was previously the greatest mean thickness yet recorded in an ice profile from the Arctic. $\$ 10$ comes from an area where theory predicts a heavy build-up of ice against the north coasts of Greenland and Ellesmere Island (Hibler, 1979, 1980). We conclude, therefore, that the region southwest of Prince Patrick Island is an exceptional area which may contain the thickest ice in the Arctic. The reason for this massive build-up must lie in the interaction between coastal topography and the wind-driven (and perhaps tide-driven) vectors of ice drift. Although numerical models predict large mean drafts along the entire Arctic Ocean coast of the Archipelago (Hibler, 1979, 1980) there is not yet a model with sufficient resolution or adequate simulation of land boundaries to predict the local phenomenon detected in these profiles. A type of ice tentatively labelled "old shorefast ice", and with a microwave signature suggestive of very rough multi-year ice, was identified during aerial surveys in autumn 1981 (Troy et al., 1984), both in Hardinge Bay and along a strip just outside the smoother shorefast ice on the west side of Prince Patrick Island.

The mean ice draft diminishes rapidly as one moves westward into the Beaufort Sea and eastward towards the interior of $M^{\prime}$ 'Clure Strait; in both regions mean drafts more comparable with the Arctic Ocean data from Sovereign and Gurnard are obtained. However, a study of $\mathrm{P}(\mathrm{h})$ shows that there are some crucial differences in the ice composition. The following statistics drawn from Table 1 compare ice compositions in the eastern Beaufort Sea beyond the shear zone (Sargo section 14) and the interior of M'Clure Strait (Sargo sections 2-8 averaged) with $S \mu$ and $G \mu$, the average compositions from the Eurasian Basin and southern Beaufort Sea respectively.

\begin{tabular}{lcccccc}
\hline \multicolumn{7}{c}{ PERCENTAGE ICE COVER } \\
Sargo & Section & $0-0.5 \mathrm{~m}$ & $0.5-2 \mathrm{~m}$ & $2-5 \mathrm{~m}$ & $>5 \mathrm{~m}$ & Mean draft \\
Sargo & $2-8$ & 1.0 & 29 & 38 & 32 & $4.45 \mathrm{~m}$ \\
& 14 & 0.0 & 11 & 58 & 31 & $4.55 \mathrm{~m}$ \\
& $\mathrm{~S}_{\mu}$ & 2.6 & 11 & 58 & 28 & $4.51 \mathrm{~m}$ \\
& $\mathrm{G} \mu$ & 0.9 & 10 & 71 & 19 & $3.81 \mathrm{~m}$ \\
\hline
\end{tabular}

Two conclusions can be drawn from the above. First, although M'Clure Strait ice resembles Arctic Ocean ice in mean draft, it contains more ice in the $0.5-2 \mathrm{~m}$ category which covers first-year ice. Therefore, ice in the interior of $\mathbf{M}^{\prime} \mathrm{Clure}$ Strait contains a large component which may have grown locally rather than being advected from the Arctic Ocean. The second conclusion is that section 14 resembles $S \mu$ far more than it resembles $\mathrm{G} \mu$, implying that ice in the eastern Beaufort Sea has characteristics closer to those of western Eurasian Basin ice than to those of ice in the southern and western Beaufort Sea. Some support for this idea comes from airborne microwave observations (Campbell et al., 1973) which have shown more first-year ice in the southern and southwestern Beaufort Sea than in the eastern Beaufort Sea.

A further conclusion which can be drawn from Table 1 is that there is a close resemblance between section G1 from the Alaskan shear zone, which begins at the $100-\mathrm{m}$ isobath $50 \mathrm{~km}$ off north Alaska, and Sargo section 12 which also begins at the inner end of the shelf break $50-100 \mathrm{~km}$ off the mouth of M'Clure Strait. This suggests that the shear zones, or 'transition zones', off Alaska and off the Canadian Archipelago are similar in general characteristics, width, and degree of ridging. Again this suggests strongly that the intensely ridged tip of Prince Patrick Island is an anomaly due to local factors.

The occurrence of young ice in winter is also demonstrated by Table 1 , which shows that ice of $<0.5 \mathrm{~m}$ draft was rare and always comprised $<3.5 \%$ of the ice cover. This is because in February the initial growth rate of ice in a newly-opened lead is very high, $12.7 \mathrm{~cm} \cdot \mathrm{day}^{-1}$ in the central Arctic Ocean according to Thorndike et al. (1975), whereas when the ice thickness has reached $50 \mathrm{~cm}$ the growth rate has decreased to $2.1 \mathrm{~cm} \cdot$ day $^{-1}$. Growing ice therefore spends much longer in the 0.5-1 $\mathrm{m}$ draft range than in the $0-0.5 \mathrm{~m}$ range, and this is reflected in the larger percentage values seen in the 0-1 m draft category of Table 1. The largest of these in the Sargo data (14.1\%) occurs over the shelf break in the Beaufort Sea (section 13), where a flaw lead is often found during winter. Smith and Rigby (1981) have analysed satellite imagery in winter from this region to show the various shapes which the flaw lead adopts; in the absence of satellite data from 1960 it is not possible to determine the shape of the flaw lead at that time, but the submarine data show that it existed. Table 4 shows that the polynyas which make up this composite flaw lead are distinguished by great width rather than great frequency, in- 
dicating a quasi-continuous body of openings rather than a very large number of narrow leads.

Figures 3 and 4 show further aspects of the winter ice composition. Sections 1 and 9 (Fig. 3), with the highest mean draft, have the most anomalous $P(h)$ functions. Section 1 displays an almost complete absence of ice $<1 \mathrm{~m}$ thick, a peak at $2 \mathrm{~m}$ and a wider peak at 3-4 m representing modest contributions from undeformed first- and multi-year ice, then a major contribution from ice (presumably ridged) in the $6-8 \mathrm{~m}$ draft range. Section 9 has minor peaks for young and first-year ice, then a massive block of ridged ice in the 4-9 $\mathrm{m}$ draft range. The anomaly lies in the way that the ridged ice is concentrated over a limited draft range, rather than being distributed over a long "tail" which behaves like most of the curves in Figure 8.

Sections 10-14 in Figure 3 behave more normally. Section 10 is typical of the Beaufort Sea shear zone, with a number of peaks for undeformed ice of various ages and a "tail" beyond $5 \mathrm{~m}$ of approximately negative exponential form. Sections 11-14 are similar. In each case undeformed multi-year ice, with a peak in the 3-4 m draft range, is an important component of the ice cover.

The sections from the interior of M'Clure Strait (Fig. 4) are quite different in character from the Beaufort Sea ice. In no case, except possibly sections 2 and 3 , can a clear peak representing undeformed multi-year ice be seen. The typical distribution for sections 3-8 displays a high narrow peak at about 2 $m$ draft, containing the undeformed first-year ice, and a wide tail due to ridging. This reinforces our earlier conclusion that the ice in M'Clure Strait is almost wholly first-year with extensive ridging, while the ice in the nearby parts of the Beaufort Sea contains more multi-year ice with a more modest degree of ridging.

The level ice statistics (Table 2) show that in the Beaufort Sea shelf zone (sections 10-14) the most frequent level ice drafts are in the range $2.3-4.2 \mathrm{~m}$, typical of multi-year ice (except for section 13 , where the 1.0 and $1.3 \mathrm{~m}$ drafts are probably due to young ice in the flaw lead which exists there). In the M'Clure Strait interior the most typical level ice drafts (1.1-1.2 m) are characteristic of first-year ice. Section 9 has a $6.0 \mathrm{~m}$ level ice contribution, which suggests that the anomalous ice masses identified in sections 1 and 9 are not necessarily entirely composed of ridged ice, but may also contain undeformed ice of extreme thickness. Such very thick ice, called "sikussak", has been identified in other locations in the Canadian Arctic Archipelago, and has been described by Walker and Wadhams (1979); it grows as fast ice in constricted channels where oceanic heat flux is reduced and precipitation increased relative to the central Arctic Ocean. Whether such ice forms a component of the Prince Patrick Island ice mass, and, if so, whether it is of local origin or has broken out of a more constricted channel elsewhere, are questions which this data set alone cannot answer.

Table 3 shows that keel frequencies and mean depths are generally similar in the $M$ 'Clure Strait interior (sections 2-8) and the Beaufort Sea Shelf (sections 10-14). Sections 1 and 9, the anomalous region, possess higher mean keel drafts and also the highest maximum keel drafts of any of the sections.

\section{Regional Variations: Summer}

Beginning from the east, the first two Seadragon sections lie within Viscount Melville Sound, a zone not profiled by Sargo. The mean ice draft in the first section, which begins at the ice edge, is only $1.57 \mathrm{~m}$, rising to $1.81 \mathrm{~m}$ in section 2 (Fig. 2). The icefield is largely composed of ice in the $0.5-2 \mathrm{~m}$ draft range (Table 1 ) with $78 \%$ of the ice $<2 \mathrm{~m}$ thick in section 1 and $69 \%$ in section 2 . In section 1 less than $0.5 \%$ of the ice cover is $>5 \mathrm{~m}$ thick, and in section 2 only $3 \%$, which indicates a scarcity of ridging. Pressure ridge statistics (Table 3) show that section 1 had only a single ridge deeper than $9 \mathrm{~m}$ $(12.73 \mathrm{~m})$, and only two other ridges deeper than $5 \mathrm{~m}$. Section 2 had a greater degree of ridging, but the maximum keel draft was still only $13.54 \mathrm{~m}$. This suggests active melting or disintegration of the few ridges that existed. The most common level ice draft categories are $1.0-1.1 \mathrm{~m}$, which in August would represent first-year ice that has undergone considerable thinning through melting. The form of $P(h)$ in Figure 5 clearly shows this predominance of young and undeformed first-year ice and the relative absence of multi-year ice and riding. As might be expected, the profiles contained a very large number of narrow leads (Table 4), comprising $18.4 \%$ of the ice cover in section 1 and $28.0 \%$ in section 2 . In fact, the numbers of leads involved (720 and 651 in $50 \mathrm{~km}$ ) represent one lead per 70-80 m of track, which is typical of an ice cover which is completely fragmented into floes. A floe diameter of 70-80 m is often found in marginal ice zones, since it represents a maximum floe size which is resistant to further break-up by waveinduced flexural failure (Goodman et al., 1980). Summarising, the ice statistics for Viscount Melville Sound are characteristic of a zone of melting first-year ice, with little or no ridging, broken up into floes of typical diameter $70-80 \mathrm{~m}$. This agrees with observations made by periscope from the submarine in the outer parts of the ice cover where ambient light was adequate. Such an ice cover would offer no problems to an icebreaker or ice-strengthened ship.

The Seadragon sections from eastern and central $M$ 'Clure Strait (3-7) show a steady rise in mean ice draft through sections 3 and 4, reaching a plateau in the centre of the strait (sections 5-7). The mean drafts here in summer lie very close to the mean drafts observed by Sargo in the preceding winter, which suggests that the same ice regime is occurring in both seasons in this region. The overall mean draft of Seadragon sections 5-7 is $4.192 \mathrm{~m}$, while that of the corresponding Sargo sections $4-8$ is $4.416 \mathrm{~m}$. The difference of $22 \mathrm{~cm}$ is what we might expect from summer melting from the bottom of a composite ice cover of this type (e.g. Maykut and Untersteiner, 1971; Thorndike et al., 1975). This question is discussed further under Central M'Clure Strait. As Figures 5 and 6 and Table 1 show, the quantity of deformed ice rises through sections 3 and 4 until in sections 5-7 it is comparable with the quantity in geographically similar sections of the Sargo profile. The ice composition, however, is somewhat different. In sections 5 and 6 (Fig. 6) there is a large amount of young ice present (peak A), and a definite component of undeformed first-year ice (peak B), but also a large amount of ice with draft 
about 4-5 m (peak C). Section 7 lacks peak B altogether. We interpret peak $C$ as being due to ridged first-year ice although, as Table 2 shows, there is significant level ice present in the 3.5-3.8 m draft range characteristic of thick multi-year ice. Pressure ridging is much more prevalent in these M'Clure Strait sections than in Viscount Melville Sound (Table 3), with maximum keel depths reaching $27.5 \mathrm{~m}$. The polynya frequency shows a radical decline - down to 352 in section 3, than 54-96 in sections 4-7 - showing that the ice regime has changed from one of discrete moderate-sized ice floes to one of continuous ice cover broken by leads. The percentage of the sea surface occupied by polynyas is high, varying from $4.9 \%$ in section 5 to $19.9 \%$ in section 7 .

Moving further westward, Seadragon section 8 occurs in the central part of the M'Clure Strait entrance (Fig. 1), whereas sections 9-11 extend out onto the Beaufort Sea shelf. Figure 2 shows a steady decline in mean ice draft across these sections, diminishing to $<2 \mathrm{~m}$ in section 11 . As Figure 7 and Table 1 show, the decline can be ascribed to two factors: 1) A rapid decline in the quantity of deformed ice present; and 2) a high incidence of young ice (38\% of the ice in section 8 has a draft of $<1 \mathrm{~m})$. The typical level ice drafts $(2.2-2.8 \mathrm{~m})$ are characteristic of multi-year ice, and the draft distributions of Figure 7 show a single peak due to undeformed ice which is multi-year rather than first-year. Pressure ridges are less frequent than in M'Clure Strait but are still as deep (the low maximum draft in section 11 is an artifact due to the short length of that section). Polynyas are more frequent than in $\mathrm{M}^{\prime} \mathrm{Cl}$ (ure Strait but are still characteristic of a coherent ice cover. We conclude that the summer ice regime in this region consists of a great deal of open water or young ice, some undeformed thicker ice which is mainly multi-year, and a modest degree of pressure ridging.

\section{Seasonal Variations}

As described earlier, we find that one characteristic ice regime was sampled only in winter (the area off Prince Patrick Island, with its extraordinary heavy ice) while another was sampled only in summer (Viscount Melville Sound and eastern M'Clure Strait). Direct seasonal comparisons are possible in two regions, central $M^{\prime}$ Clure Strait and the Beaufort Sea shelf.

Central M'Clure Strait. There are two good geographical correspondences between sections in this region (Fig. 1) in that Seadragon $5 \equiv$ Sargo 6, and Seadragon 6 三Sargo 7. More generally, Seadragon 5-7 and Sargo 4-8 occupy the same overall region. We have already shown that the mean drafts in summer and winter differ by only $22 \mathrm{~cm}$, suggesting an identical ice mass which has been subject only to summer melt between the two experiments. The following statistics, drawn from Tables 1-3, offer further comparisons:

$\begin{array}{cc}\begin{array}{c}\text { Seadragon 5-7 } \\ \text { (summer) }\end{array} & \begin{array}{c}\text { Sargo 4-8 } \\ \text { (winter) }\end{array} \\ 4.2 & 0.4 \\ 19 & 32\end{array}$

\begin{tabular}{|c|c|c|c|}
\hline Percent level ice & $\begin{array}{l}5 \mathrm{~m} \\
5 \mathrm{~m}\end{array}$ & $\begin{array}{l}49 \\
28 \\
49.8\end{array}$ & $\begin{array}{l}36 \\
32 \\
60.1\end{array}$ \\
\hline Keels per km, & $\begin{array}{l}5 \mathrm{~m} \text { cutoff } \\
9 \mathrm{~m} \text { cutoff }\end{array}$ & $\begin{array}{l}6.31 \\
2.17\end{array}$ & $\begin{array}{l}1.74 \\
0.76\end{array}$ \\
\hline $\begin{array}{l}\text { Mean keel draft, } \\
\text { Maximum keel }\end{array}$ & $\begin{array}{l}5 \mathrm{~m} \text { cutoff } \\
9 \mathrm{~m} \text { cutoff } \\
\text { lraft }\end{array}$ & $\begin{array}{r}8.56 \mathrm{~m} \\
12.13 \mathrm{~m} \\
27.52 \mathrm{~m}\end{array}$ & $\begin{array}{r}9.57 \mathrm{~m} \\
12.88 \mathrm{~m} \\
25.71 \mathrm{~m}\end{array}$ \\
\hline
\end{tabular}

The distribution of ice among depth categories supports the idea that first-year ice $(0.5-2 \mathrm{~m}$ draft) that was present in winter became deformed and moved into the $2-5 \mathrm{~m}$ category, creating an equivalent area of open water or young ice (0-0.5 $\mathrm{m}$ ) and leaving the overall mean draft virtually unaltered. This could have occurred in spring, when partial break-up may have permitted increased mobility of the ice cover without allowing any overall drift into or out of the strait. The pressure ridge statistics show that in summer there were 3-4 times as many ridges per $\mathrm{km}$ as in the preceding winter, although their mean draft was slightly lower. Again, this is in accord with the idea of first-year ice becoming ridged in situ, although many puzzles remain, such as the fact that there is less ice deeper than $5 \mathrm{~m}$ in summer than in winter, despite the much greater number of pressure ridges. In the absence of supporting satellite imagery we cannot be sure that the hypothesis of in situ ice deformation is valid, but the appearance of $P(h)$ in the corresponding sections of Figures 4 and 6 is strongly suggestive.

Beaufort Sea shelf. The seasonal variation here is more straightforward. The relevant sections for comparison are Sargo 10-14 with Seadragon 9-11, although the Sargo transect was done somewhat further to the north and extended further into the Arctic Ocean (Fig. 1). In winter (Fig. 3) the ice composition is characteristic of the Canada Basin shear zone, and is similar to Alaskan shear zone profiles obtained by Wadhams and Horne (1980). There is heavy ridging near the coast, which diminishes with increasing distance out into the Arctic Ocean. The undeformed ice is mainly multi-year, and there is little young ice present except in a well-defined area (Sargo section 13) which lies over a recurrent winter flaw lead. In summer (Fig. 7) the ice has become very broken up, yielding an ice composition with a large amount of young ice or open water, but with a predominant undeformed ice type which is still multi-year. The quantity of ice deeper than $5 \mathrm{~m}$ is much reduced in summer relative to winter. Pressure ridging is also heavier in winter. The following average keel frequencies and depths are taken from Table 3 ; the function $\mu \bar{h}^{2}$ is proportional to the keel volume per unit area of icefield.

$\begin{array}{clccc} & & \mu & \hbar & \mu \hbar^{2} \\ \text { Seadragon 9-11 } & \mathrm{h}_{0}=5 \mathrm{~m} & 2.64 & 7.46 \mathrm{~m} & 146.9 \\ \text { (summer) } & \mathrm{h}_{\mathrm{o}}=9 \mathrm{~m} & 0.55 & 11.43 \mathrm{~m} & 71.8 \\ \text { Sargo 10-14 } & \mathrm{h}_{\mathrm{o}}=5 \mathrm{~m} & 2.03 & 9.11 \mathrm{~m} & 168.5 \\ \text { (winter) } & \mathrm{h}_{\mathrm{0}}=9 \mathrm{~m} & 0.85 & 12.51 \mathrm{~m} & 133\end{array}$

For keels deeper than $9 \mathrm{~m}$ the ridging is much heavier in winter than in summer, while keels deeper than $5 \mathrm{~m}$ are actually more numerous in summer, although the ice volume in- 
volved is greater in winter on account of the greater mean draft.

\section{ACKNOWLEDGEMENTS}

The authors are very grateful to Dr. Waldo Lyon, Director, Arctic Submarine Laboratory, San Diego, for releasing these data to us. The analysis was carried out with support from the Office of Naval Research under contracts N00014-80-G-0002 and N00014-83-G-0008. We thank Rob Massom for diagrams.

\section{REFERENCES}

ACKLEY, S.F., HIBLER, W.D. III, KUGZRUK, F.K., KOVACS, A. and WEEKS, W.F. 1976. Thickness and roughness variations of Arctic multiyear sea ice. Hanover, NH: US Army Cold Regions Research and Engineering Laboratory. Report 76-18. 25 p.

CAMPBELL, W.J., GLOERSEN, P., NORDBERG, W. and WILHEIT, T.T. 1973. Dynamics and morphology of Beaufort Sea ice determined from satellites, aircraft and drifting stations. NASA Goddard Space Flight Center, Report X-650-73-194. 27 p.

GOODMAN, D.J., WADHAMS, P. and SQUIRE, V.A. 1980. The flexural response of a tabular ice island to ocean swell. Annals of Glaciology 1:23-27.

HIBLER, W.D. III. 1975. Statistical variations in Arctic sea ice ridging and deformation rates. In: Ice Tech 75: Symposium on Icebreaking and Related Technologies, Montreal, April 1975. New York: Society of Naval Architects and Marine Engineers. J1-J9.

1979. A dynamic thermodynamic sea ice model. Journal of Physical Oceanography 9:815-846.

1980. Modelling a variable thickness sea ice cover. Monthly Weather Review 108(12):1943-1973.

, WEEKS, W.F. and MOCK, S.J. 1972. Statistical aspects of sea-ice ridge distributions. Journal of Geophysical Research 77(30):5954-5970.

LOWRY, R.T. and WADHAMS, P. 1979. On the statistical distribution of pressure ridges in sea ice. Journal of Geophysical Research 84(C5):24872494.

MAYKUT, G.A. and UNTERSTEINER, N. 1971. Some results from a time dependent thermodynamic model of sea ice. Journal of Geophysical Research 76:1550-1575.

ROTHROCK, D.A. and THORNDIKE, A.S. 1980. Geometric properties of the under side of sea ice. Journal of Geophysical Research 85:3955-3963.

SMITH, M. and RIGBY, B. 1981. Distribution of Polynyas in the Canadian Arctic. Canadian Wildlife Service Occasional paper 45:7-28.

STEELE, CDR. G.P., U.S.N. 1962. Seadragon, Northwest Under the Ice. New York: E.P. Dutton \& Co. Inc. 255 p.

THORNDIKE, A.S., ROTHROCK, D.A., MAYKUT, G.A. and COLONY, R. 1975. The thickness distribution of sea ice. Journal of Geophysical Research 80:4501-4513.

TROY, B.E., HOLLINGER, J.P., RAMSEIER, R.O., ASMUS, K.W., HARTMAN, M.F. and LUTHER, C.A. 1984 (in press). Microwave emission from High Arctic sea ice during freeze-up. Journal of Geophysical Research.

WADHAMS, P. 1981. Sea-ice topography of the Arctic Ocean in the region $70^{\circ} \mathrm{W}$ to $25^{\circ} \mathrm{E}$. Philosophical Transactions of the Royal Society of London, Series A 302:45-85.

1983a. Sea ice thickness distribution in Fram Strait. Nature 305(5930): 108-111.

$1983 \mathrm{~b}$. Arctic sea ice morphology and its measurement. Journal of the Society for Underwater Technology 9(2):1-12.

. 1983c. The prediction of extreme keel depths from sea ice profiles. Cold Regions Science and Technology 6:257-266.

and HORNE, R.J. 1980. An analysis of ice profiles obtained by submarine sonar in the Beaufort Sea. Journal of Glaciology 25:401-424.

WALKER, E.R. and WADHAMS, P. 1979. Thick sea-ice floes. Arctic 32(2): 140-147.

WILLIAMS, E., SWITHINBANK, C.W.M. and ROBIN, G. de Q. 1975. A submarine sonar study of Arctic pack ice. Journal of Glaciology $15: 349-362$. 